\title{
Monetary Policy and the New View of International Capital Movements
}

UNTIL FAIRLY RECENTLY, THE STANDARD THEORY concerning international financial capital flows - movements of nondirect investment items in the capital account-related capital flows to levels of interest differentials. According to this "flow theory," an increase in foreign short-term interest rates would increase the outflow of capital from the United States, and as long as foreign interest rates remained higher than American rates, the flow would continue. Conversely, one way for the United States to improve its balance on capital account would be to raise its rates, and as long as U.S. rates remained higher than foreign rates, the capital account would show a reduced deficit.

This relationship of capital flows to levels of interest rates was rather widely accepted in the mid-1960s by both theorists and empiricists in international economics. For example, the famous articles by Robert A. Mundell on the simultaneous maintenance of external and internal balance generally assumed the relationship: ". . . at high rates of interest the net inflow of capital will be larger, or the net outflow will be smaller, than at low rates of interest." ${ }^{1}$ In a well-known study, Peter B. Kenen also cor-

* I wish to acknowledge, in addition to assistance from participants in the Brookings panel, the comments of Burton Malkiel, assistance from Raymond D. Hill in all aspects of preparation, and support from National Science Foundation Research Grant Number GS, 1972.

1. "The Monetary Dynamics of International Adjustment under Fixed and Flexible Exchange Rates," Quarterly Journal of Economics, Vol. 74 (May 1960), p. 230. See also Mundell, "The Appropriate Use of Monetary and Fiscal Policy for Internal and External Stability," International Monetary Fund Staff Papers, Vol. 9 (March 1962), pp. 70-79. 
related capital flows with levels of interest differentials and set forth some evidence of interest sensitivity. ${ }^{2}$

The implicit model relating capital flows to interest rate levels may also have been part of the reasoning behind "Operation Twist"-the attempt to boost short-term rates to improve the capital account while keeping long-term rates down to encourage domestic investment spending and, indirectly, economic growth. Similarly, the interest equalization tax (IET), which reduced net returns on U.S. holdings of longer-term foreign assets relative to those on U.S. assets-the equivalent of a drop in foreign rates relative to U.S. rates-was generally expected to promote improvement in the capital account as long as it was in effect.

The implications of this view for the monetary-fiscal policy mix were fairly clear: To improve the balance of payments while maintaining a given path of domestic demand and employment, the prescription would be to tighten up on monetary policy, thus raising interest rates, and at the same time to ease fiscal policy. Maintenance of a given level of demand would hold the trade and current account balances more or less unchanged, and higher interest rates would reduce the outflow of capital.

\section{Capital Theory and International Capital Flows}

This flow theory of international financial capital movements coexisted with seemingly contradictory, but also widely accepted, theories of real investment demand and portfolio distribution. A leading theory of investment demand is derived from the proposition that the desired or equilibrium capital stock is related to the level of the interest rate-or, more precisely, the user cost of owned capital goods-and expected output. ${ }^{3}$ On this view of investment behavior, it is changes in interest rates, other things equal, that cause changes in the desired stock of capital. These generate

2. Peter B. Kenen, "Short-term Capital Movements and the U.S. Balance of Payments," in The United States Balance of Payments, Hearings before the Joint Economic Committee, 88 Cong. 1 sess. (1963), pp. 153-91.

3. For an exposition of this view, see Dale W. Jorgenson, "Capital Theory and Investment Behavior," in American Economic Association, Papers and Proceedings of the Seventy-fifth Annual Meeting, 1962 (American Economic Review, Vol. 53, May 1963), pp. 247-59. This approach has been implemented empirically by Jorgenson and various collaborators. Charles W. Bischoff also bases his work on essentially the same theoretical model, but uses a less restrictive empirical specification than Jorgenson's. See his "The Effect of Alternative Lag Distributions," in Gary Fromm (ed.), Tax Incentives and Capital Spending (Brookings Institution, forthcoming). 
the investment flows analogous to international capital flows, which are, after all, simply changes in asset and liability positions.

More relevant to the question of international financial capital flows is the model of portfolio distribution developed by Markowitz and Tobin. ${ }^{4}$ Their theory makes the distribution of assets depend on the rates of return and estimates of risk for the alternative assets. For any given set of interest rates and risk estimates, there will be an equilibrium distribution of assets in a portfolio (among domestic and foreign assets, for example); it is changes in interest rates that lead to changes in this allocation, or flows of capital, given the size of the portfolio. Applied to international financial capital, this theory implies that, at any given point in time, raising domestic interest rates will produce a one-shot stock-adjustment inflow of capital as portfolios are redistributed. This redistribution may, of course, be spread over several periods. But once a new portfolio equilibrium is reached, the flow will cease. This view was put succinctly by Tinbergen in 1956:

Both debt management and discount policy can indeed attract a certain amount of capital from abroad, corresponding with the interest offered. When demand for assets reaches its equilibrium at the new interest rate, no further inflow of foreign investment will, however, occur unless a further rise in rates is effectuated. ${ }^{5}$

On this view, it is rising, not high, interest rates that cause a continuing capital inflow (or reduced outflow) ${ }^{6}$

\section{INTRODUCTION OF THE "NEW VIEW"}

Since the mid-1960s, a number of investigators have attempted to bring the theory of international capital flows into line with the theories of capital accumulation and portfolio distribution just described. In general, this

4. Harry M. Markowitz, Portfolio Selection: Efficient Diversification of Investments (John Wiley \& Sons, 1959); James Tobin, "Liquidity Preference as Behavior Towards Risk," Review of Economic Studies, Vol. 25 (February 1958), pp. 65-86; and "The Theory of Portfolio Selection," in F. Hahn and F. P. R. Brechling (eds.), The Theory of Interest Rates (Macmillan, 1965).

5. Jan Tinbergen, Economic Policy: Principles and Design (Amsterdam: NorthHolland Publishing Co., 1964), p. 111.

6. This point was also recognized in the early sixties by Tobin and Johnson. See James Tobin, "Economic Progress and the International Monetary System," Proceedings of the Academy of Political Science, Vol. 27 (May 1963), p. 84; and Harry G. Johnson, "Towards a General Theory of the Balance of Payments," in Richard E. Caves and Harry G. Johnson, Selection Committee for the American Economic Association, Readings in International Economics (Homewood, Ill.: Richard D. Irwin, 1968), p. 375. 
"new view" of international capital movements makes the fraction of total assets held abroad a function of the level of interest rates and estimates of risk both at home and abroad. ${ }^{7}$ For certain kinds of assets, such as shortterm claims on foreigners, other variables, such as exports, are added to the list of explanatory variables.

In this view, the stock of assets held abroad depends on the level of interest rates, the stock of total assets, and the levels of other variables, such as exports. An increase in U.S. interest rates will then cause a shift in the stock of assets toward the United States-the "stock-shift effect"and, assuming a continuing growth in total assets, a reallocation of marginal additions to total assets towards the United States-the "continuing flow effect." There is a presumption, discussed below, that the flow effect is small relative to the stock effect.

With stock-shift effects large compared with flow effects, the changes in capital movements that policy makers perceive shortly after changes in the stance of monetary policy-or in money and credit conditions in general-are likely to be temporary. To a large extent, it is rising, not high, interest rates that induce permanent improvement in the capital account. As Tobin put it, "A country cannot expect to cover a basic deficit on current or long-term investment account indefinitely by attracting short-term money, unless it is prepared to jack its interest rates higher and higher." 8

The implication of the new view, then, is that policy steps like the interest equalization tax and "Operation Twist"- to the extent it actually was

7. Initial contributions to this literature include William H. Branson, Financial Capital Flows in the U.S. Balance of Payments (Amsterdam: North-Holland Publishing Co., 1968); Thomas D. Willett, "A Portfolio Theory of International Short-Term Capital Movements" (Ph.D. thesis, University of Virginia, 1967); and Thomas D. Willett and Francesco Forte, "Interest Rate Policy and External Balance," Quarterly Journal of Economics, Vol. 83 (May 1969), pp. 242-62. More recent contributions include R. C. Bryant and Patric H. Hendershott, Financial Capital Flows in the Balance of Payments of the United States: An Exploratory Empirical Study, Princeton Studies in International Finance, No. 25 (Princeton University, Department of Economics, International Finance Section, 1970); Norman C. Miller and Marina v. N. Whitman, "A Mean-Variance Analysis of United States Long-Term Portfolio Foreign Investment," Quarterly Journal of Economics, Vol. 84 (May 1970), pp. 175-96; C. H. Lee, "A Stock-Adjustment Analysis of Capital Movements: The United States-Canadian Case," Journal of Political Economy, Vol. 77 (July-August 1969), pp. 512-23; and John E. Floyd, "International Capital Movements and Monetary Equilibrium," American Economic Review, Vol. 59 (September 1969), pp. 472-92.

8. Tobin, "Economic Progress," pp. 84-85. 
successful in "twisting"- stimulate an essentially one-time improvement in the capital account. Although there is a continuing-flow effect, it is probably small relative both to the initial stock effect and to subsequent stock shifts stemming from later changes in interest rates. In other words, the continuing-flow effects could tend to be swamped in the data by later stock shifts. On the other hand, the outflow following an easing of monetary policy will also be largely temporary and can be handled by official financing or use of reserves, rather than by retreating from a policy presumably designed to meet domestic needs.

This, then, in fairly general terms, is the new stock-adjustment view of international capital movements and its main implication for policy. The next section describes more precisely the relationship between the stockshift and continuing-flow effects of a given change in interest rates.

There follows a brief summary of some results of the empirical application of the stock-adjustment model to the data on U.S. financial capital flows. This application yields some rough estimates of the sensitivities of U.S. capital movements to changes in credit conditions, represented by changes in interest rates, the income velocity of money, and a credit rationing measure devised by Jaffee and Modigliani. ${ }^{9}$

The last two sections set out the implications of the analysis for domestic monetary policy, both in general and in terms of the outlook for 1970-71, and conclude with a few observations on the implications of the new view for monetary independence and proposals for reform of the international exchange rate system.

\section{The Stock Equilibrium Model of Capital Movements}

The portfolio distribution approach to the explanation of capital flows relates equilibrium stocks of assets to levels of rates of return and risk. For any given set of foreign and domestic interest rates and risk evaluations, there will be a given distribution of an individual's assets. Holdings of any asset-in particular, claims on foreigners $C^{f}$-will change as total assets or interest rates change. The discussion here focuses first on the stock and flow results of an interest rate change, and then on a few problems of empirical application of this model to the data.

9. Dwight M. Jaffee and Franco Modigliani, "A Theory and Test of Credit Rationing," American Economic Review, Vol. 59 (December 1969), pp. 850-72, esp. pp. 865-67. 


\section{INTEREST RATE CHANGES: STOCK AND FLOW EFFECTS}

Suppose the distribution of assets-or total wealth $W$-is a function only of interest rates and risk estimates, and thus does not depend on total wealth itself. A simple linear portfolio distribution function can then be written as

$$
C^{f}=W\left(a_{0}+a_{1} i^{d}+a_{2} i^{f}+a_{3} R\right),
$$

where

$C^{f}=$ claims on foreigners, or assets held abroad,

$W=$ total assets,

$i^{d}=$ domestic interest rates,

$i^{f}=$ foreign interest rates (the last two may be viewed as summarizing the entire term structure),

$R=$ a set of risk evaluations (lumped together only because the focus of this paper is on the effects of interest rate changes). ${ }^{10}$

Here $C^{f} / W$ depends only on interest rates and estimates of risk. This is probably the form of the portfolio distribution equation most widely used in empirical investigations of the financial sector, and it is generally accepted as a "maintained hypothesis" in recent work on international capital movements. ${ }^{11}$

The rate of change of $C^{f}$ per period $t$, with interest rates and $R$ constant and total assets growing, is given by

$$
\dot{C}^{f}=\dot{W}\left(a_{0}+a_{1} i^{d}+a_{2} i^{f}+a_{3} R\right),
$$

where $\dot{C}^{f}$ is defined as $d C^{f} / d t$. What then is the effect of an interest rate change on the stock $C^{f}$ at an initial level of $W$, and on the flow of capital $\dot{C}^{f}$ as $W$ grows?

From equation (1), the effect of an increase in the domestic interest rate $\Delta i^{d}$ is given by

$$
\text { Stock effect }=\Delta C^{f}=W a_{1} \Delta i^{d} .
$$

10. The equation is stated as a linear form only for ease of exposition. The results would be exactly the same if it were stated more generally as $C^{f}=W\left[f\left(i^{d}, i^{f}, R\right)\right]$.

11. See, for instance, William C. Brainard and James Tobin, "Pitfalls in Financial Model Building," in American Economic Association, Papers and Proceedings of the Eightieth Annual Meeting, 1967 (American Economic Review, Vol. 58, May 1968), p. 101; and E. E. Leamer and R. M. Stern, Quantitative International Economics (Allyn and Bacon, 1970), p. 103. 
The effect on the flow generated by growth in total assets is obtained from equation (2),

$$
\text { Flow effect }=\Delta \dot{C}^{f}=\dot{W} a_{1} \Delta i^{d} .
$$

Thus in this fairly general, and widely used, form of the portfolio distribution model, the ratio between the continuing-flow effect and the stockshift effect of an interest rate change is given by

$$
\frac{\text { Flow effect }}{\text { Stock effect }}=\frac{\dot{W} a_{1} \Delta i^{d}}{W a_{1} \Delta i^{d}}=\frac{\dot{W}}{W}=\text { growth rate of } W .
$$

If total assets $W$ are growing at 10 percent per year, then the annual flow effect of a change in interest rates will be 10 percent of the stock-shift effect.

But what if the $C^{f} / W$ ratio has a positive time trend due, perhaps, to increasing awareness of U.S. investors of investment possibilities abroad? Won't this raise the flow effect relative to the stock effect? The answer is a qualified "No." If the time trend does not reflect increasing interest sensitivity, but rather changing tastes among assets, changing risk evaluations, or increasing knowledge of opportunities, then the flow-stock relationship is not affected. This can be seen by adding a time trend to the expression in parentheses in equation (1). ${ }^{12}$ The trend in this case does not change the relationship between the flow and stock effects of an interest rate change; the ratio remains equal to the growth rate of total assets.

But if there is an upward trend in interest sensitivity, then the relative magnitudes of the flow and stock effects would be changed. The change would work in the direction of increasing U.S. capital outflows on average, however, only if foreign rates were rising relative to U.S. rates. Since that was not the way relative interest rates generally moved in the 1960s, an increase in the international interest sensitivity of liquid funds would have meant an augmented flow of funds into, not out of, the United States. ${ }^{13}$

12. This gives $C^{f}=W\left(a_{0}+a_{1} i^{d}+a_{2} i^{f}+a_{3} R+a_{4} t\right)$, with a stock-shift effect of $\Delta C^{f}=W a_{1} \Delta i^{d}$, and $\dot{C}^{f}=\dot{W}\left(a_{0}+a_{1} i^{d}+a_{2} i^{f}+a_{3} R+a_{4} t\right)+a_{4} W$, so that the flow effect is still $\Delta \dot{C}^{f}=\dot{W} a_{1} \Delta \dot{i}^{d}$, and the ratio is still $\dot{W} / W$.

13. Implementation of a model with a trend in interest sensitivity would involve adding terms in $i^{d} t$ and $i^{f} t$ to equation (1). In empirical work to date, there is no evidence that this improves the explanation of capital flows. Splitting the data into 1960-64 and 196569 samples, for example, does not assign higher coefficients to interest rate changes in the latter period. 
Thus as a working hypothesis, subject to testing for increasing interest sensitivity, the flow-stock relationship of equation (3) can be adopted.

\section{PROBLEMS OF EMPIRICAL APPLICATION}

The principal empirical implication of the flow-stock relationship derived above is that it will be hard to detect continuing-flow effects in aggregate data that come from a world of continually changing interest rates. With frequent changes in interest rates and the other determinants of equilibrium holdings of portfolio assets, the stock-shift effects will probably tend to overwhelm the flow effects in the data. This means that the existence of the continuing-flow effects will be hard to verify empirically, and will probably have to be built into the estimates by the use of an equation like (1).

Application of the portfolio model to the data requires numerous modifications. First, the existence of complications like transaction costs and tax laws means that adjustment to changes in interest rates will be lagged and incomplete. Since redistribution of existing portfolios may impose extra transaction costs, the redistribution may be accomplished by reallocating additions to the portfolio and leaving the existing stock unchanged. Such a process can spread the stock-shift effect over several quarters. If empirical work does not take this lag into account, it may appear to detect a relation between interest rate levels and capital flows.

Furthermore, variables other than interest rates affect the measured flows. The next section takes account of the effect exports have on shortterm claims on foreigners through trade finance. A measure of the velocity of money and the Jaffee-Modigliani credit rationing index will be included to reflect availability effects that are not perfectly correlated with interest rates. Some allowance must also be made for the effect of the balance-ofpayments programs and the interest equalization tax on U.S. flows.

Risk estimates, which enter the theoretical model of capital flows, are hard to specify empirically, and will be left out of the empirical estimates. This omission would seem on initial consideration to be particularly serious in the case of international capital movements. But that is basically an empirical question: If shifts in risk estimates in fact cause major movements of any category of capital, they should be reflected in large errors in an equation that omits such considerations. In addition, changes in risk estimates may cause only a reallocation of assets held abroad: If a foreign exchange crisis involving, say, the Deutschemark and the French franc 
causes U.S. investors to switch from French to German investments, this will not affect the total of U.S. claims on foreigners.

Even with all of these empirical difficulties, fairly regular relationships can be found between capital flows and the key determinants identified above-interest rates, money velocities, and total assets. The next section reports briefly some results of the application of the portfolio stockadjustment theory to the determination of changes in U.S. claims on private foreigners. These claims are divided into three categories that exhaust the asset side of the capital account, with the exception of direct investment. This discussion will provide an idea of the expected magnitude of the stock and flow effects of changes in interest rates and velocity. The estimates are then used in discussing the probable effects of monetary policy on the assets side of the U.S. capital account in 1970-71. I am currently working on the estimation of equations on the liability side, but the results are not ready to be reported. Flows of foreign-owned capital would move in the same direction as U.S. capital in response to changes in monetary conditions, so they would add to the effects of alternative monetary policies reported in Table 2 .

\section{The Explanation of U.S. Capital Flows}

The results reported here come from the application to the 1960-69 quarterly data of an equation that is essentially a first-differenced form of equation (1). I will seek to explain changes in U.S. holdings of three categories of foreign assets: (1) short-term private claims $\Delta C^{s}$; (2) long-term nondirect, nonbanking claims $\Delta C^{l}$, here called "portfolio claims"; and (3) long-term banking claims $\Delta B$.

Short-term (less than one year) private claims include short-term bank loans and acceptances extended to foreigners; trade credit extended by U.S. firms to foreigners; short-term foreign securities held by Americans; and deposits of Americans in foreign banks, including holdings of Eurodollars by Americans. Portfolio claims consist of foreign stocks and bonds held by Americans, excluding equities representing direct investment abroad, while long-term banking claims are term loans to foreigners.

In general, I have used U.S. and various foreign short- and long-term interest rates and income velocities of money $v$ as measures of U.S. credit conditions. I have also experimented with the Jaffee-Modigliani index $c r$ as an explicit measure of U.S. credit rationing. If U.S. credit conditions tighten either because there is an exogenous increase in credit demand with 
given supply conditions, or because growth of the money supply is slowed in order to retard growth in GNP, the whole set of indicators of monetary tightness-interest rates, velocity, and credit rationing - would be expected to rise. The velocity and credit rationing variables should represent movements in the domestic opportunity cost of foreign lending to the extent that changes in credit conditions are not fully reflected in changes in interest rates. In addition, these variables may reflect a tendency of U.S. lenders to put foreign borrowers near the end of the credit rationing line. These indicators need not be perfectly correlated with one another, so I have experimented with all three measures in each equation. In the equations for U.S. capital flows, all three variables play a significant role.

The general form of the equations to be estimated for U.S. capital flows-changes in U.S. claims on foreigners-is

$$
\begin{aligned}
\Delta C^{f}= & a_{0}+a_{1} \Delta W+a_{2} \Delta\left(W i^{U S}\right)+a_{3} \Delta\left(W v^{U S}\right) \\
& +a_{4} \Delta(W c r)+a_{5} \Delta\left(W i^{f}\right)+a_{6} \Delta\left(W v^{f}\right),{ }^{14}
\end{aligned}
$$

where

$\Delta C^{f}=$ change in U.S. claims on foreigners, not seasonally adjusted, in millions of dollars at quarterly rates,

$W=$ wealth, measured by household net worth in trillions of dollars in the equation for $\Delta C^{s}$ and $\Delta C^{l}$, and by total bank assets in billions of dollars in the equation for $\Delta B$,

$i=$ the appropriate short- and long-term interest rates, in percentage points,

$v=$ income velocity of money, defined as the ratio of GNP (seasonally adjusted annual rate) to $M_{1}$ (the sum of demand deposits and currency, seasonally adjusted),

$c r=$ Jaffee-Modigliani credit rationing measure, base period $=1.0$.

The superscripts $C A N, S W$, and $U K$ denote the interest rate and velocity variables of Canada, Switzerland, and the United Kingdom, respectively, while $E D$ denotes the Eurodollar rate. Subscripts $s$ and $l$ denote shortand long-term securities, respectively.

14. Equation (4) can be obtained from (1) by adding terms in $c r$ and $v$, dropping the unobserved $R$, multiplying through by $W$ the terms in parentheses (including $v$ ), and finally taking first differences. No adjustment has been made here for a possible trend in $v$, which would be very difficult to estimate in the 1960-69 data. Reducing the $\Delta v$ series to allow for a constant trend would simply reduce all the $\Delta(W v)$ terms proportionately, leaving the coefficients of these terms unchanged, with the net effect showing up in the constant term $a_{0}$. Thus the results would not be changed by adjustment for a trend in $v$. 
Each term on the right-hand side of equation (4) potentially represents a weighted sum of its current and lagged values. In general, lag lengths were extended until the coefficients of the furthest lagged values became insignificant. This procedure was followed to allow for the possibility of an extended lag in the stock-shift adjustment of financial capital to changes in monetary conditions. As will be seen shortly, lag lengths generally do not exceed three or four quarters, suggesting that the stock adjustment is generally completed within a year after a change in monetary conditions.

The equations for short- and long-term portfolio claims were estimated including three seasonal dummies, while no seasonal variation was found in the equation for long-term banking claims. The coefficients of the seasonal dummies are reported and discussed in Appendix A.

\section{SHORT-TERM CLAIMS}

Several modifications of the basic equation (4) must be made in order to apply it to changes in U.S. short-term claims on private foreigners $\Delta C^{s}$. First, it is necessary to recognize that a large proportion of U.S. short-term lending is related to trade credit. To take account of this factor, I have added terms involving current and lagged changes in merchandise exports $X$. Exports are measured in millions of dollars, at quarterly rates, not seasonally adjusted..$^{15} \mathrm{~A}$ given stock of trade credit will finance a given flow of trade, so that it is levels of exports that are related to stocks of assets, and it is changes in exports that generate capital flows.

Thus if the flow of exports increases from one level to another, the effect on the balance of payments will be partially offset by a stock-shift increase in trade credit. After this stock shift is completed, the increase in exports becomes a clear gain to the balance of payments.

The second modification is the addition of variables to account for the existence of the voluntary foreign credit restraint program (VFCR) initiated by the U.S. government in February 1965. In general, the program initially required banks to limit their increase in short-term claims to 5

15. In theory, the effect of changes in exports on claims on foreigners should depend on interest rates $i$ at home and abroad, just as would the effect of an increase in total assets $W$. Thus, in the equation for short-term claims, cross-product terms in $X$ and $i$, as well as in $W$ and $i$, should ideally be included in the equation explaining $\Delta C^{s}$. With only forty quarterly observations, this would add too many variables to the regression equations. After experiments with the alternative use of $W$ and $X$ as the basic scale variable, it was clear that $W$ was statistically superior, so terms in $X$ were simply added to the $\Delta C^{s}$ equation, as stated in the text. 
percent in 1965 and 4 percent in 1966, leaving the ceiling at the end of 1966 at 109 percent of claims outstanding at the end of 1964. During this period, short-term outflows were reduced substantially (becoming negative in some quarters) so that outstanding claims were well below the ceiling at the end of 1966. With this leeway in mind, the ceiling on outstanding claims was held constant at 109 percent of the 1964 level in 1967, and it was both reduced to 103 percent and made mandatory in 1968.

In an earlier paper, Willett and I suggested that in 1965 the banks made a downward adjustment in their stock of claims on foreigners to get sufficiently below the ceiling to conduct business more or less normally thereafter. ${ }^{16}$ It was this leeway that troubled the administration in 1967 and 1968.

Given this description of events, two dummy variables can be added to the equation explaining $\Delta C^{s}$ to reflect the reactions to the programs as interpreted above. The first dummy variable, DStockl, is set at unity in 1965:1-1965:3, and zero for other periods. This should yield an estimate of the initial stock-shift effect as the banks got below their ceilings. The second dummy, DFlow1, is set at zero through $1965: 3$, and unity thereafter. This should yield an estimate of the continuing effect of the program on the outflow of U.S. private short-term capital. Finally, the equation for $\Delta C^{s}$ was estimated using a number of foreign interest rates, including the Eurodollar rate, and foreign velocities. Only the British interest rate proved to be significant. In addition, it turned out that the credit rationing index cr plays no role in the equation for $\Delta C^{s}$. The "final" equation for $\Delta C^{s}$ is:

$$
\begin{aligned}
& \Delta C_{t}^{s}=-211.1+3582.4 \Delta W_{t}+0.18 \Delta X_{t}+0.39 \Delta X_{t-1} \\
& -113.2 \Delta\left(W i_{s}^{U S}\right)_{t-2}-454.9 \Delta\left(W v^{U S}\right)_{t}+48.7 \Delta\left(W i_{s}^{U K}\right)_{t} \\
& +34.7 \Delta\left(W i_{s}^{U K}\right)_{t-1}-573 \\
& R^{2}=0.83, \text { standard error }=151.7, \text { Durbin-Watson }=2.05 \text {. }
\end{aligned}
$$

The numbers in parentheses beneath coefficients here and in subsequent empirical equations are $t$ statistics.

16. William H. Branson and Thomas D. Willett, "Policy Toward Short-term Capital Movements: Some Implications of the Portfolio Approach," presented at the Universities-National Bureau of Economic Research Conference on International Mobility and Movement of Capital, Brookings Institution, Jan. 30-Feb. 1, 1970, publication forthcoming. 
The equation uses quarterly data for 1960-68. However, 1963:3 was omitted from the sample period because it had an unusually large residual, presumably reflecting the shift into short-term assets when the interest equalization tax was imposed on long-term capital. Furthermore, the 1969 data were excluded because the dock strike that began in December 1968 temporarily upset the relationship between claims and exports. If $\Delta X$ is smoothed for the period 1968:4-1969:3, the equation including 1969 is not significantly different from (5). The inclusion of the 1969 data substantially increases the significance of the U.S. velocity term, changing its coefficient to -999.7 , and its $t$ ratio to 2.33 . The importance of the velocity term in the most recent data suggested that it be retained in (5). Details on the estimation of the several versions of (5) are set out in Appendix A.

It should be noted that the longest lag length in equation (5) is two quarters. This indicates that the stock-shift effect on short-term claims will be completed within three quarters after a change in interest rates.

\section{LONG-TERM PORTFOLIO CLAIMS}

Two minor modifications of the basic capital flow equation (4) must be made to apply it to flows of U.S. long-term portfolio capital $\Delta C^{l}$, which is residually defined as changes in U.S. claims on foreigners exclusive of direct investment, short-term claims, and long-term banking claims. The first modification is the inclusion of an adjustment for the interest equalization tax, which was imposed on U.S. purchases of foreign long-term portfolio assets in July of 1963. Canadian issues were exempted. The tax essentially reduces the return on foreign portfolio assets by imposing an additional cost on their purchase. Ideally, to take account of the tax, the relevant foreign long-term interest rates should be adjusted downward to the effective rates of return net of the tax. But since the Canadian long-term interest rate is the only foreign long-term rate in the equation for longterm portfolio claims, I have used a dummy for the tax, IET, that is set at unity in 1963:3-1963:4 and zero otherwise. ${ }^{17}$

The second modification is the inclusion of the Eurodollar rate in the equation to reflect credit conditions in Europe. The Eurodollar rate $i^{E D}$ was included in the first estimated version of all the asset equations in order to test generally for sensitivity of U.S. capital flows to pressures

17. This treatment incorrectly implies that the tax has no continuing-flow effect. This flaw would be corrected if the IET were entered as an adjustment to foreign long-term rates; I am continuing to experiment with this more refined approach. 
from the Eurodollar market. The rate is highly significant in the equation for long-term portfolio capital.

The equation for $\Delta C^{l}$ was estimated using a number of foreign longterm interest rates and velocity measures, as reported in Appendix A. None of the velocity measures was significant, and of the foreign longterm rates, only the Canadian rate $i_{l}^{C A N}$ had a $t$ ratio greater than unity. The Canadian long-term rate was retained in the final equation because more than half of U.S. long-term portfolio capital flows have been bilateral with Canada since the interest equalization tax was imposed.

The "final" estimated equation for $\Delta C^{l}$ is:

$$
\begin{aligned}
& \Delta C_{t}^{l}=84.2+4686.7 \Delta W_{t}-597.7 \Delta\left(W v^{U S}\right)_{t}-47.6 \Delta(W c r)_{t} \\
& +50.9 \Delta\left(W i^{E D}\right)_{t}+31.7 \Delta\left(W i^{E D}\right)_{t-1} \\
& +46.7 \Delta\left(W i_{l}^{C A N}\right)_{t}-428.9 I E T \text {. } \\
& R^{2}=0.69 \text {, standard error }=116.9, \text { Durbin-Watson }=1.49 \text {. }
\end{aligned}
$$

The equation is estimated on the forty quarterly observations from 1960:1 through 1969:4. The U.S. velocity measure and credit rationing index both play a fairly significant, and surprisingly independent, role in explaining U.S. portfolio capital flows. When either variable is dropped from the equation, the coefficient of the other does not change much. It is surprising that the U.S. long-term bond rate does not enter the equation. It was thoroughly insignificant in all trials; presumably it is dominated by movements in U.S. velocity and credit rationing, and in the Canadian longterm bond rate, which is fairly highly correlated with the U.S. rate. The longest lag length in equation (6) is one quarter, which suggests that stock adjustment of portfolio claims to changes in monetary conditions is particularly rapid.

\section{LONG-TERM BANKING CLAIMS}

To complete the set of equations explaining U.S. financial capital flows, I have estimated a number of equations for changes in long-term banking claims on foreigners $\Delta B$. These are by far the least stable of the equations on the asset side of the capital account, and the equation is presented here only because the U.S. velocity measure plays a highly significant role in all versions of it. 
From 1960 to the third quarter of 1963, quarterly movements of longterm banking claims fluctuated in a band between an inflow of $\$ 50$ million and an outflow of $\$ 150$ million. In the fourth quarter of 1963 , apparently in reaction to the interest equalization tax, the outflow shot up to nearly $\$ 500$ million, as foreign borrowers seemed to change sources of funds. The outflow subsided to $\$ 75$ million in $1964: 2$, but it rose steadily to a peak of $\$ 460$ million in 1965:1, apparently in anticipation of the voluntary restraint program, which was initiated in February 1965. The flow then moved to an inflow of $\$ 200$ million in 1965:2, as the banks reduced claims on foreigners to get under their VFCR ceilings. Then, from 1965:3 through 1969 , the movement fluctuated roughly between an inflow of $\$ 150$ million and an outflow of $\$ 50$ million, significantly below the normal outflow of the period before the IET and VFCR.

To account for these extremely large movements from 1963:4 to 1965:2, I have used three dummy variables. The first, IET3, is a dummy set at unity in 1963:4 and zero otherwise; it essentially eliminates that observation and gives us a measure of the IET effect on the change in long-term banking claims on foreigners. The second, $D A 3$, takes on the values of unity in 1964:4-1965:1 and zero otherwise to account for the outflow in anticipation of the voluntary restraint program. The third, DFlow3, is a flow dummy that takes on the value of unity from 1965:1 on, and zero previously. This shifts the estimated outflow down from the higher range of the period before late 1963 to the lower range of the period after early 1965.

The scale variable in the equation for long-term banking claims is total bank assets $A$, in billions of dollars, taken from the Federal Reserve data on the flow of funds. The equation was estimated using a number of foreign interest rates and velocity measures, as well as the U.S. long-term rate, velocity, and credit rationing measure. Several European long-term rates and the Eurodollar rate were tested as measures of credit conditions in Europe, relevant to the flow of long-term banking claims. The "final" equation for $\Delta B$ is:

$$
\begin{aligned}
& \Delta B_{t}=89.7+6.91 \Delta A_{t}+0.38 \Delta\left(A i_{l}^{U K}\right)_{t-1}+0.66 \Delta\left(A i_{l}^{S W}\right)_{t-1} \\
& \text { (1.83) (1.55) } \\
& \text { (1.78) } \\
& -\sum_{i=1}^{5} w_{i} \Delta\left(A v^{U S}\right)_{t-i}+\underset{(4.31)}{418.4 I E T 3}+\underset{1}{364.4 D A 3-93.4 D F l o w 3} \\
& R^{2}=0.74, \text { standard error }=93.6 \text {, Durbin-Watson }=2.29 \text {. }
\end{aligned}
$$


Equation (7) is estimated on the forty quarterly observations from 1960 through 1969. Seasonal dummies were not included in the estimate because no seasonal pattern on $\Delta B$ was discernible. Aside from the dummies, the only really significant variable in (7) is the U.S. velocity term. The coefficients of the $\Delta\left(A v^{U S}\right)_{t-i}$ terms are as follows:

$\begin{array}{lccccc}\text { Lag lengths (quarters) } & 1 & 2 & 3 & 4 & 5 \\ \text { Coefficient } & -0.92 & -1.33 & -1.31 & -0.87 & 0 \\ & (1.09) & (2.52) & (2.05) & (1.71) & \end{array}$

The sum of the $\Delta\left(A v^{U S}\right)_{t-i}$ coefficients is -4.43 , with a standard error of 1.76.18 Neither the U.S. long-term interest rate nor the credit rationing index was at all significant in any of the estimates leading to (7).

As suggested earlier, the equation for $\Delta B$ is highly sensitive to the adjustments made for the disturbances of the 1963:4-1965:1 period. This sensitivity raises doubts about any conclusions that may be drawn from (7) except one-the U.S. velocity term is significant, with a lag length of about a year, in all versions of the equation. As shown in Appendix A, when the equation is reestimated on the sample period 1965:4-1969:4, the coefficients of the velocity terms become larger and more significant. This justifies the inclusion of the velocity sensitivity of $\Delta B$ in the multiplier estimates to be discussed in the next section. The four-quarter lag in changes in U.S. velocity in equation (7) suggests that it takes a little more than a year for long-term banking claims to complete the stock adjustment that follows a change in monetary conditions. Thus long-term banking claims have the slowest speed of adjustment of the three categories of assets that are considered in this paper.

\section{STOCK AND FLOW MULTIPLIERS FOR U.S. CAPITAL FLOWS}

The estimated equations for U.S. financial capital flows-the nondirect investment asset side of the capital account-yield the stock-shift multipliers shown in Table 1 for changes of 1 percentage point in the relevant interest rates, and for an increase of 0.1 in the credit measure and in U.S. velocity. (The current level of velocity is about 5 , with GNP near $\$ 1$

18. The coefficients were estimated using the Almon technique, with a second-degree polynomial and a restriction that the last coefficient ( $i=5$ here) take on a zero value. Thus two Almon variables enter the regression to estimate the four coefficients shown here. 
Table 1. Stock-Shift Multipliers of U.S. Holdings of Selected Foreign Assets Resulting from Increases in Selected Variables ${ }^{a}$

Millions of dollars

\begin{tabular}{|c|c|c|c|c|c|c|}
\hline \multirow{2}{*}{$\begin{array}{l}\text { Increase } \\
\text { and } \\
\text { variable }\end{array}$} & \multicolumn{2}{|c|}{$\begin{array}{c}\text { Short-term } \\
\text { private claims }\end{array}$} & \multicolumn{2}{|c|}{$\begin{array}{c}\text { Long-term } \\
\text { portfolio claims }\end{array}$} & \multicolumn{2}{|c|}{$\begin{array}{c}\text { Long-term } \\
\text { banking claims }\end{array}$} \\
\hline & Flow $^{\mathrm{b}}$ & $\operatorname{Lag}^{\mathrm{c}}$ & Flow $^{\mathrm{b}}$ & $\operatorname{Lag}^{\mathrm{c}}$ & Flow $^{\mathrm{b}}$ & $L_{a g}{ }^{\mathrm{c}}$ \\
\hline Mean quarterly flow, 1960-69 & $\$ 226$ & ... & $\$ 279$ & ... & $\$ 27$ & ... \\
\hline \multicolumn{7}{|l|}{ Increase of 1 percentage point in: } \\
\hline U.S. short-term rate & -342 & 3 & $\ldots$ & ... & $\ldots$ & ... \\
\hline U.K. short-term rate & +252 & 2 & ... & $\ldots$ & .. & $\ldots$ \\
\hline Eurodollar rate & $\ldots$ & $\ldots$ & +249 & 2 & ... & $\ldots$ \\
\hline Canadian long-term rate & ... & $\ldots$ & +141 & 1 & $\ldots$ & $\ldots$ \\
\hline U.K. long-term rate & $\ldots$ & $\ldots$ & ... & $\ldots$ & +186 & 2 \\
\hline Swiss long-term rate & $\ldots$ & $\ldots$ & $\ldots$ & $\cdots$ & +285 & 2 \\
\hline \multicolumn{7}{|l|}{ Increase of $0.1 \mathrm{in}:$} \\
\hline Credit rationing index & ... & $\ldots$ & -14 & 1 & .. & . \\
\hline U.S. velocity of money & -137 & 1 & -181 & 1 & -191 & 5 \\
\hline
\end{tabular}

Sources: Data on short-term private claims-equation (5); on long-term nondirect, nonbanking claimsequation (6); on long-term banking claims-equation (7).

a. The effects are calculated assuming that in 1969:4 total U.S. household net worth equaled $\$ 3.02$ trillion and total U.S. bank assets equaled $\$ 431.4$ billion.

b. Plus sign indicates balance-of-payments outflow through increased holdings; minus sign, inflow.

c. This is the number of quarters required for completion of the stock shift after a change in an interest rate or velocity. It is the longest lag on the relevant variable in the estimated equation reported in the text.

trillion and $\mathrm{M}_{1}$ about $\$ 200$ billion.) The stock-shift multipliers are calculated at the 1969:4 values of the wealth or asset scale variables. For $\Delta C^{s}$ and $\Delta C^{l}$, the relevant variable is household net worth $W$, while for $\Delta B$ it is total bank assets $A$.

To obtain the stock-shift multiplier of an interest rate, one multiplies the change in $i$, which is 1.0 by assumption, by the level of the relevant scale variable to obtain $W \Delta i$, and then multiplies this by the estimated coefficient of that $i$ term in the relevant equation. For example, in the equation for short-term claims $\Delta C^{s}$, the coefficient of the U.S. short-term rate term $\Delta\left(W i_{s}^{U S}\right)$ is -113.2 . Thus with $W$ at $\$ 3.02$ trillion, the $i_{s}^{U S}$ multiplier in Table 1 is given by

$$
-113.2 \times 3.02 \times 1.0=-\$ 341.9 \text { million. }
$$

An increase of 1 percentage point in the U.S. Treasury bill rate will cause a stock-shift inflow of $\$ 342$ million in short-term claims over three quarters. 
Similarly, the coefficient of $\Delta\left(W v^{U S}\right)$ in equation (5) for $\Delta C^{s}$ is -454.9 , so that the $v^{U S}$ multiplier for an increase of 0.1 in $v^{U S}$, is given by

$$
-454.9 \times 3.02 \times 0.1=-\$ 137.3 \text { million. }
$$

As noted earlier, the continuing-flow effect (or multiplier) of a given interest rate change is equal to the growth rate of the underlying asset or wealth variable times the stock-shift effect. With both household net worth $W$ and total bank assets $A$ growing at about 7 percent annually in recent years, the continuing-flow multipliers would be 0.07 times the stock-shift multipliers of Table 1. For example, the stock-shift multiplier of $\Delta i_{s}^{U S}$ in the $\Delta C^{s}$ equation is minus $\$ 342$ million. Thus with $W$ growing at 7 percent per year, the continuing-flow effect of a 1 percentage point increase in $i_{s}^{U S}$ would be

$$
-341.9 \times 0.07=-\$ 23.9 \text { million per year. }
$$

One important explanatory variable has been left out of the multiplier table-U.S. exports. In equation (5) for $\Delta C^{s}$, the coefficient of $\Delta X_{t}$ is 0.18 and that of $\Delta X_{t-1}$ is 0.39 . This says that if the quarterly rate of U.S. exports rises by $\$ 100$ million, there will be a one-shot outflow of about $\$ 60$ million in short-term trade credit over two quarters.

\section{INTERPRETATIONS AND QUALIFICATIONS OF THE RESULTS}

The empirical estimates reported here are obviously very rough and approximate. The data are quite volatile and there is a natural inclination to deal with first differences or flows, so that an $R^{2}$ of 0.7 is a welcome sight. ${ }^{19}$

But even with these rough estimates, three points emerge clearly. First, the problem of capital flows is tractable econometrically. The contention that capital movements are too volatile and unpredictable to be dealt with econometrically simply won't stand up. There are very strong statistical regularities in the data, and they are consistent with traditional portfolio theory explanations of what moves capital.

Second, the estimates presented here and in Appendix A indicate the magnitude of reaction of capital flows on the asset side to be expected when

19. An $R^{2}$ of 0.7 won't even get you into the league in most time-series contests. This gives the capital movements game a standing a bit like that of soccer in the United States. 
monetary policy shifts. They are roughly confirmed by estimates by Miller and Whitman, who use somewhat different definitions and variables. ${ }^{20}$

Third, the econometric results presented here do not "test" the portfolio stock-adjustment theory in any significant way. Rather, the equations are rough estimates of the parameters conditional on the assumption that the theory is correct; the theory has been imposed on the data. The fact that the results do not violate common sense encourages the view that the theory is, in fact, correct. But this is no test of an hypothesis.

The net result of these considerations is that, if international capital movements follow the same principles that other capital movements do, and especially if they are subject to the theory of portfolio distribution, then the present estimates should provide policy makers a reasonable view of the international implications of shifts in monetary policy. With this reassurance, however dubious, these estimates can now be applied, first, to the problem facing monetary policy in the remainder of 1970 and in 1971, and second, to the question of national monetary independence and proposals for improving the processes for adjusting the balance of payments.

\section{Capital Flows with a Shift in Monetary Policy:} The Outlook for 1970-71

The estimates of the previous section suggest that a shift to monetary ease will cause a fairly large stock-shift increase in the capital account deficit, but that after two or three quarters the continuing-flow effect will be fairly small. The simulation of the differential impact of two assumptions concerning money supply growth through 1971:4 shown in Table 2 illustrates this point. ${ }^{21}$ The first three columns of Table 2 present the differential results for the level of the U.S. velocity measure of two assumptions concerning monetary growth. In both cases, growth in GNP in current prices

20. See Miller and Whitman, "Mean-Variance Analysis," and "The Outflow of Short-term Funds from the United States: Adjustments of Stocks and Flows," presented at the Universities-NBER Conference on International Mobility and Movement of Capital, Brookings Institution, Jan. 30-Feb. 1, 1970, publication forthcoming.

21. The Table 2 simulation implicitly assumes that foreign interest rates do not respond to changes in the U.S. interest rate and velocity. To the extent that foreign rates do respond, they would move in the same direction, making the change in differentials smaller than the change in U.S. values. Thus the net effect of the interest differential on U.S. capital outflow would be smaller than that reported in Table 2. 
Table 2. Effects on U.S. Capital Flows of Differences in Growth of the Money Supply, by Quarter, Third Quarter 1970 to Fourth Quarter 1971

Dollar amounts in millions at quarterly rates

\begin{tabular}{|c|c|c|c|c|c|c|c|}
\hline \multirow{3}{*}{$\begin{array}{c}\text { Year } \\
\text { and } \\
\text { quarter }\end{array}$} & \multicolumn{3}{|c|}{ Velocitya } & \multirow{3}{*}{$\begin{array}{l}\text { Effect of dif- } \\
\text { ferential on } \\
\text { three-month } \\
\text { Treasury } \\
\text { bill rate } \\
\text { (percentage } \\
\text { points) }\end{array}$} & \multirow{2}{*}{\multicolumn{3}{|c|}{ Effects on capital outflows }} \\
\hline & \multicolumn{2}{|c|}{$\begin{array}{l}\text { Monetary growth } \\
\text { assumptions }\end{array}$} & \multirow[b]{2}{*}{$\begin{array}{l}\text { Differ- } \\
\text { ential }\end{array}$} & & & & \\
\hline & High & $\frac{\text { Low }}{\text { Lows }}$ & & & $\begin{array}{c}\text { Velocity } \\
\text { differential }\end{array}$ & $\begin{array}{c}\text { Bill rate } \\
\text { differential }\end{array}$ & Total \\
\hline \multirow{3}{*}{$\begin{array}{r}19703 \\
4\end{array}$} & (1) & (2) & (3) & (4) & (5) & (6) & (7) \\
\hline & 4.730 & 4.798 & -0.068 & -1.22 & $\$ 225.2$ & 0 & $\$ 225.2$ \\
\hline & 4.697 & 4.833 & -0.136 & -1.41 & 259.6 & 0 & 259.6 \\
\hline \multirow{4}{*}{$\begin{array}{r}19711 \\
2 \\
3 \\
4\end{array}$} & 4.697 & 4.83 & -0.136 & -0.89 & 76. & $\$ 438.0$ & 514.8 \\
\hline & 4.697 & 4.833 & -0.136 & -0.89 & 90.5 & 77.6 & 168.1 \\
\hline & 4.697 & 4.833 & -0.136 & -0.89 & 76.6 & $-185.0^{\mathrm{c}}$ & $-108.4^{\mathrm{c}}$ \\
\hline & 4.697 & 4.833 & -0.136 & -0.89 & 38.3 & 5.0 & 43.3 \\
\hline
\end{tabular}

a. Velocity is defined as GNP/M1. Both assumptions about monetary growth set the annual rate of growth of GNP at 6 percent in 1970:3-1971:4. The low assumption puts monetary growth at an annual rate of 3 percent in 1970:3-1970:4 and at 6 percent thereafter. The high assumption puts it at 9 percent in 1970:3-1970:4 and at 6 percent thereafter.

b. The changes in the rate on three-month Treasury bills are calculated from the following equation, constructed using the total short- and long-run interest velocities given by Franco Modigliani, Robert Rasche, and J. Phillip Cooper, "Central Bank Policy, the Money Supply, and the Short-term Rate of Interest," Journal of Money, Credit and Banking, Vol. 2 (May 1970), Table 1, equation (3), p. 171:

c. Inflow.

$$
\left(\frac{\Delta r_{s}}{r_{s}}\right)_{t}=10.4\left(\frac{\Delta\left(v^{-1}\right)}{v^{-1}}\right)_{t-1}-12.5\left(\frac{\Delta\left(v^{-1}\right)}{v^{-1}}\right)_{t}
$$

was set at 6 percent (annual rate) from 1970:3 through 1971:4. For a high monetary growth rate, I chose 9 percent (annual rate) for 1970:3-1970:4, and 6 percent thereafter. For a low monetary growth assumption, I chose 3 percent (annual rate) for 1970:3-1970:4, and 6 percent thereafter. This pattern of assumptions permits study of the effects of a one-time change in velocity, since the equal 6 percent growth rates of GNP and money supply after 1970:4 hold the two velocities constant thereafter. Thus the first two columns of Table 2 show the movements in velocity implicit in the high and low assumptions about monetary growth. The third column shows the difference in velocity reflecting the differential impact of the two monetary paths.

Combining a single GNP path with both the high and low monetary paths involves an assumption about the monetary-fiscal policy mix. To realize the specified GNP path with the low monetary path, fiscal policy must supply compensatory stimulus. With the high monetary path, fiscal policy presumably would be tighter, and interest rates would fall more 
substantially. Thus the Table 2 simulation reports the differential effect of a shift in the mix of monetary and fiscal policy that leaves the GNP path unchanged. The impact for capital flows of a shift to monetary ease would be lessened if a fixed fiscal policy were assumed so that the GNP path were higher with the higher monetary path.

Table 2 also shows the differential effect of the alternative monetary paths on the three-month Treasury bill rate, using a recent estimate of a demand-for-money function made by Modigliani, Rasche, and Cooper. ${ }^{22}$ The bill rate is, of course, lower for the higher monetary path. The difference between the alternative bill rates grows to 1.41 percentage points in 1970:4 and then narrows to 0.89 point as the velocities remain constant after that quarter. This movement reflects the overshooting of interest rates in response to changes in money supply, a usual result in models in which actual money holdings are adjusted to desired levels with a lag.

In the last three columns of Table 2 are the differences in the outflow of U.S. financial capital that stem from the differences between the high and low assumptions about monetary growth. ${ }^{23}$ These numbers are in no way predictions of actual outflows, but rather are estimates of the differential impact of the high monetary path compared with the low path, given the assumed GNP path.

Column (5) shows the differential impact that works directly through velocity. The outflow due to the velocity differential falls from more than $\$ 250$ million in 1970:4-an annual rate of $\$ 1$ billion-to less than $\$ 40$ million in 1971:4.

Column (6) records the estimated effect of the bill rate differential. The entire effect is on short-term capital-the only equation in which the bill rate is significant. With a two-period lag, the differential of 1.22 percentage points in 1970:3 brings a $\$ 438$ million outflow in 1971:1. Because the differential then increases to 1.41 points, a further outflow of $\$ 78$ million ensues. Then as the interest rate differential narrows, an inflow of $\$ 185$ million results. Finally, its influence settles down to a continuing-flow effect of $\$ 5$ million per quarter.

The total differential impact is shown in the last column of Table 2. The difference between the stock-shift and continuing-flow effects is striking.

22. Franco Modigliani, Robert Rasche, and J. Philip Cooper, "Central Bank Policy, the Money Supply, and the Short-term Rate of Interest," Journal of Money, Credit and Banking, Vol. 2 (May 1970), Table 1, equation (3), p. 171.

23. The effect of a change in the credit rationing index $c r$ is not included because I have no ready way to connect it to velocity changes. In effect, I assume $c r$ the same for both the high and low monetary paths. 
For three quarters there is a very large stock shift. The policy maker looking at the situation at the end of 1971:1 would see that an increase in the outflow of U.S. capital of over $\$ 1$ billion had occurred in the previous three quarters as a result of taking the high instead of the low monetary path.

This kind of effect, coupled with perhaps a similar effect on the liabilities side of the capital account, might be of major concern to the monetary authority who worries about the balance of payments. Indeed the concern might be sufficient to cause him to regret choosing the high monetary path, but only if he failed to realize that the phenomenon was mainly a transitory stock-shift effect. By 1971:4, the differential effect on the outflow would be down to a quarterly rate of less than $\$ 50$ million. Thus if the stock-shift outflow can be handled by official financing-that is, by persuading a foreign central bank to hold the dollars-or absorbed as a reserve loss, the steady-state differential effect of the shift to monetary ease is small, here perhaps $\$ 200$ million a year on the U.S. assets side of the capital account.

One central point for monetary policy is brought out by the purely illustrative numbers of Table 2. It is the basic theme that has run through this paper. When monetary policy eases and velocity and interest rates fall, there will be a substantial capital outflow over two or three quarters due to the change in policy. After this transition, the continuing flow owing to the change in policy will be small. But events will be misinterpreted if the monetary authority implicitly holds a flow theory of capital movements. In that case, as he watches the large capital outflow in the months following the easing of policy, he will believe that outflow will continue, and at least question the wisdom of the easier monetary policy. Thus the flow theory could lead to a substantial overestimate of the damage easier money would do to the balance of payments, and could result in a monetary stance that was overly restrictive in terms of vital domestic objectives. But if the monetary authority takes the correct stock-adjustment view, he will realize that the large outflow, while certainly worrisome, is transitory and manageable, and that the longer-run effects will be relatively minor. This view would lead to a better-and smaller-estimate of the effect of an easier policy on the balance of payments and thus put the international constraint on monetary policy in its correct-and diminished-role.

To be sure, a sufficiently large stock-shift outflow could reduce reserves enough to call the existing value of the parity rate into question, even if 
speculators knew the capital flow was a one-time shift. But the shifts that are under consideration here seem reasonably small compared with total reserves.

A final point is that the stock-shift effects of changes in monetary policy are not only large, but also uncertain. The estimates come from equations that, while reasonably good for this stage of econometric work in the field, still have large standard errors. This additional bit of uncertainty with respect to the effects of monetary policy reinforces the point that, wherever possible, monetary and fiscal policy should be applied in the same direction. ${ }^{24}$ The support of fiscal policy will reduce the magnitude of necessary changes in monetary policy, and thus reduce the size of the probable resulting stock shift.

\section{Monetary Independence and Exchange-Rate Systems}

The previous section pointed out that the stock-adjustment view of capital flows will give a correct, and generally small, estimate of the continuing outflow generated by an easing of monetary policy. This also implies that monetary policy changes, within a reasonable range of variation, will not have a major continuing effect on the balance of payments in a full employment economy. From one point of view, this is bad: It reduces the number of effective policy instruments for balance-of-payments adjustment. But from another point of view, this is good: It frees monetary policy to serve domestic objectives. If monetary policy will have only small continuing effects on capital flows, then its stance can be determined mainly with reference to the domestic situation.

The gradual drift of the capital account balance, generated by growing portfolios in a world of domestically focused monetary policies, could be compensated for by a gradual change in exchange rates that adjusts the current account to balance the capital account. One major argument against such a "crawling peg" system has been that it will impose an additional interest rate constraint on monetary policy.$^{25}$ It is argued on a flow

24. The role of uncertainty is studied in William C. Brainard, "Uncertainty and the Effectiveness of Policy," in American Economic Association, Papers and Proceedings of the Seventy-ninth Annual Meeting, 1966 (American Economic Review, Vol. 57, May 1967), pp. 411-25.

25. This point is discussed at more length in Branson and Willett, "Policy Toward Short-term Capital Movements." 
theory basis that a downward drift in an established equilibrium exchange rate will generate a continuing capital outflow, requiring the depreciating country to maintain its interest rates above those abroad by an amount equal to the rate of change of the exchange rate.

But in the stock-adjustment model, with expected rates of change of exchange rates playing a role analogous to that of interest rates, the shift from an expected rate of change of zero to some negative value will bring a stock-shift outflow. When the rate stabilizes at a lower level and the expected rate of change returns to zero, there will be an equal and opposite stock-shift inflow. Thus if official financing (so-called recycling) of these transitory shifts can be arranged, there is no need for interest rates to be adjusted to compensate for the crawl of the exchange rate.

This strengthens the view that exchange rates should be adjusted gradually through some kind of crawling peg system to provide changes in the current account that compensate for movements in the capital account. In this case, monetary policy can be partially freed from the balance-ofpayments constraint and used with an eye more toward domestic needs.

APPENDIX A

\section{Estimation of U.S. Financial \\ Capital Flows ${ }^{1}$}

\section{Short-term Claims}

Equation (5) above is the final form of the equation for short-term claims $\left(\Delta C^{s}\right)$ estimated over the period 1960:1-1968:4 (excluding 1963:3). Seasonal variation was found to be significant and dummy variables for each quarter of the year were estimated. The values (and the corresponding $t$ statistics) were: -125.6 (1.55) for the first quarter; -122.0 (1.50) for the second quarter; and -356.2 (4.23) for the third quarter.

In addition to those variables retained, a number of others were tried.

1. The appendixes were prepared by Raymond D. Hill. 
The coefficient of the Eurodollar rate was insignificant and had the wrong sign in earlier versions. The coefficient of the Canadian Treasury bill rate was larger than its standard error over the period 1960:1-1964:4, but was less significant over the longer sample. Canadian, United Kingdom, and a weighted average of European velocities failed to be significant.

When data for 1969:1-1969:4 are included in the sample period, the resulting equation is:

$$
\text { (A.1) } \begin{aligned}
\Delta C_{t}^{s}= & 508.9+5667.0 \Delta W_{t}+0.19 \Delta X_{t}+0.12 \Delta X_{t-1} \\
& (6.01)(2.83)(2.06)(1.28) \\
+ & +51.2 \Delta\left(W i_{s}^{U K}\right)_{t}+28.5 \Delta\left(W i_{s}^{U K}\right)_{t-1}-87.6 \Delta\left(W i_{s}^{U S}\right)_{t-2} \\
& (1.97)(1.06) \quad(1.80) \\
& -1162.7 \Delta\left(W v^{U S}\right)_{t}-468.0 \mathrm{DStock} 1-80.5 \text { DFlow } 1 .
\end{aligned}
$$

Seasonal dummies: $Q_{1}=-199.2, Q_{2}=-162.6, Q_{3}=-419.6$.

$$
\text { (1.96) (1.57) }
$$

$$
R^{2}=0.72 \text {, standard error }=200.9 \text {, Durbin-Watson }=2.39 \text {. }
$$

The results in equation (A.1) are similar to those in (5) except that the sum and significance of the coefficients of the two export variables are greatly reduced. This is due apparently to the disturbance in the timing relationship between claims and exports created by a dock strike in early 1969, which caused a deep cut in exports in 1969:1 and a sharp rise in the next quarter.

Equation (A.2) attempts to account for the dock strike in 1969.

$$
\text { (A.2) } \begin{aligned}
\Delta C_{t}= & 441.9+5140.0 \Delta W_{t}+0.18 \Delta X_{t}+0.44 \Delta X_{t-1}+62.9 \Delta\left(W i_{s}^{U K}\right)_{t} \\
& (5.98)(3.09) \quad(1.81) \quad(4.06) \quad(3.00) \\
& +34.8 \Delta\left(W i_{s}^{U K}\right)_{t-1}-101.8 \Delta\left(W i_{s}^{U S}\right)_{t-2}-999.7 \Delta\left(W v^{U S}\right)_{t} \\
& (1.55) \quad(2.53) \\
& -514.0 \text { DStock1 }-109.2 \text { DFlow1. }
\end{aligned}
$$

Seasonal dummies: $Q_{1}=-155.1, Q_{2}=-102.1, Q_{3}=-425.8$.

$$
\text { (1.80) (1.18) }
$$

$$
R^{2}=0.80 \text {, standard error }=169.5 \text {, Durbin-Watson }=2.43 \text {. }
$$

The export series was smoothed out by replacing the value for 1969:1 with the actual value for 1968:4 plus the average quarterly increase in exports over 1969, and by replacing the value for 1969:2 with the actual value for 
1968:4 plus twice the average increase. As a result of this operation the coefficients of the export variables are restored approximately to their former size and level of significance.

In both (A.1) and (A.2) the coefficient of U.S. velocity rises substantially in size and significance. This increase reinforces the case in favor of including U.S. velocity in equation (5), where it is a marginally significant variable.

\section{Long-term Portfolio Claims}

Equation (6) of the text is the final form of the equation for long-term portfolio claims $\Delta C^{l}$ estimated over the period 1960:1-1969:4. The estimated seasonal dummy variables were:

$$
Q_{1}=-3.0, Q_{2}=-53.5, Q_{3}=-112.4 \text {. }
$$

The U.S., U.K., Swiss, and German long-term bond rates were also tried, as well as the U.S., U.K., and Canadian short-term rates. None of these rates was significant, and the coefficients of most had the wrong signs. The U.K., Canadian, and a weighted average of European velocities were also tried without success.

Contrary to what one might expect, U.S. velocity and the credit rationing variable appear to act independently of one another. Leaving one of the two out of the equation has very little effect on the size and significance of the coefficient of the other.

\section{Long-term Banking Claims}

Equation (7) above is the final form of the equation for long-term banking claims $\Delta B$ estimated over the period 1960:1-1969:4. No significant seasonal pattern was found.

Other interest rates tried were the Canadian long-term rate, the U.S. short and long rates, and the Eurodollar rate. Foreign velocities and the credit rationing variable were also tried.

The size and significance of the coefficients of (7) were extremiely sensitive to the exact form chosen for the program dummies. As a result an 
equation for long-term banking claims was estimated on data from 1965:4 to 1969:4 in order to avoid the disturbances of the programs. U.S. velocity continued to play the most important role in this new set of equations, of which (A.3) is the "best."

$$
\text { (A.3) } \begin{aligned}
\Delta B= & 219.7+0.15 \Delta\left(A i^{U K}\right)_{t}+0.12 \Delta\left(A i_{l}^{E D}\right)_{t}+1.35 \Delta\left(A v^{U K}\right)_{t} \\
& (2.23)(1.16) \\
& +\sum_{i=0}^{5} w_{i} \Delta\left(A v^{U S}\right)_{t-i} . \\
R^{2}= & 0.63, \text { standard error }=53.1 \text {, Durbin-Watson }=2.74 .
\end{aligned}
$$

The coefficients of $\left(A v^{v S}\right)_{t-i}$ are:

$\begin{array}{ccccccc}\text { Lag length } & 0 & 1 & 2 & 3 & 4 & 5 \\ \text { Coefficients } & -0.24 & -1.61 & -2.27 & -2.22 & -1.46 & 0.0 \\ & (0.47) & (3.12) & (3.51) & (3.52) & (3.49) & \\ \Sigma & w_{i}=-7.79, \text { standard error of sum }=2.32 .\end{array}$

APPENDIX B

\section{Symbols and Sources of Data Used in Regressions}

$\Delta C^{s}=$ change in U.S. short-term claims on foreigners, in millions of dollars at quarterly rates, from David T. Devlin, "The U.S. Balance of Payments: First Quarter 1970," Survey of Current Business, Vol. 50 (June 1970), Table 1, lines 38 and 40, pp. $36 \mathrm{ff}$.

$\Delta C^{l}=$ change in U.S. long-term nonbanking, nondirect investment claims on foreigners, in millions of dollars at quarterly rates, from ibid., lines $34,35,36$, and 39 .

$\Delta B=$ change in long-term banking claims on foreigners, in millions of dollars at quarterly rates, from ibid., line 37.

$W=$ U.S. household net worth, in trillions of dollars, from unpublished data from the Federal Reserve Board-MIT econometric model; available from the author. 
$A=$ total bank assets, in billions of dollars, from unpublished flow of funds data from the Board of Governors of the Federal Reserve System; available from the author.

$i_{s}^{U S}=$ rate on three-month U.S. Treasury bills, in percent, from Organisation for Economic Co-operation and Development (OECD), Main Economic Indicators, relevant issues.

$i_{s}^{U K}=$ rate on 91-day U.K. Treasury bills, in percent, from ibid.

$i_{s}^{E D}=$ rate on three-month Eurodollar deposits in London, in percent, from Bank of England Quarterly Bulletin, relevant issues.

$i_{l}^{C A N}=$ rate on long-term Canadian government bonds, in percent, from OECD, Main Economic Indicators, relevant issues.

$i_{l}^{S W}=$ rate on long-term Swiss government bonds, in percent, from International Monetary Fund, International Financial Statistics, relevant issues.

$i_{l}^{U K}=$ rate on long-term U.K. government bonds, in percent, from OECD, Main Economic Indicators, relevant issues.

$v=$ income velocity of money, defined as the ratio of gross national product to $\mathbf{M}_{1}$, demand deposits plus currency; both GNP (at annual rates) and $M_{1}$ in billions of dollars, seasonally adjusted; GNP and $\mathrm{M}_{1}$ from OECD, Main Economic Indicators, relevant issues.

$c r=$ credit rationing measure, from Dwight $\mathrm{M}$. Jaffee and Franco Modigliani, "A Theory and Test of Credit Rationing," American Economic Review, Vol. 59 (December 1969), pp. 850-72.

$X=$ U.S. merchandise exports, in millions of dollars at quarterly rates, from Devlin, "U.S. Balance of Payments," Table 1, line 3. 


\section{Comments and Discussion}

Lawrence Krause: I am fundamentally sympathetic with Branson's approach, and I share his view that the difference between portfolio adjustment and flow adjustment is a major one. The difference seems simple enough-perhaps it may even strike some as old hat. But it is not fully understood and it remains relevant. Let me offer an example out of the newly released 1970 Annual Report of the International Monetary Fund. Referring to the U.S. balance of payments, it said: "In view of the sizable deficit in (basic) transactions, it is necessary for the monetary authorities to pay particular attention to the implications of domestic credit policy for the level of U.S. short-term interest rates in relation to those abroad."

That statement takes a flow view of the implications of interest rates for the balance of payments. It also seems to focus attention on rate differentials. This implies that, if there were a parallel shift of U.S. and foreign interest rates, nothing would happen. But Branson's illustrative numbers of Table 1 show that net flows would take place even with a parallel shift. Finally, the statement underlines the deficit on basic transactions-a concept that has less and less meaning for the United States.

Branson argues and works to demonstrate that the econometric problems of the portfolio adjustment approach are tractable. I agree, but I would like to point out some of the problems. The data are very poor, involving gaps and errors of measurement. Moreover, institutional peculiarities distort the flows, and special factors can have a large and erratic impact from time to time. For these reasons, the specification of relationships becomes very important, perhaps the most crucial part of the work. And I do have problems with some of the specified relationships in the paper.

First, I would note the omission of any risk variable. One of the essential ingredients in a portfolio shift between foreign and domestic assets is the 
difference in risk. Exchange rates introduce a special risk into international finance. To an American choosing foreign assets, this may not be very important because he can acquire them denominated in U.S. dollars. The exchange risk is assumed by the borrower. But this risk must be introduced in an analysis of U.S. liabilities because these reflect the portfolio choices of foreigners. The whole liability side remains a missing element of Branson's work.

This paper illustrates the usual plight of the specialist in international economics. Often, more exact theory is needed to determine the international implications of events and policies than is needed in domestic economics. For example, the question constantly arises of whether, and to what extent, a shift from a corporate income tax to a value-added tax would help the balance of payments. The international experts cannot answer that question because the theory of incidence is not refined enough. The public finance experts have not supplied the domestic information needed to answer the international questions.

In the present case of monetary problems, it may well be good enough to have a little black box that generates domestic results when certain monetary conditions are changed. But one would like a better understanding of the international consequences. How does a velocity change influence the choice between domestic and foreign assets? It is not enough that the variable works econometrically. The multipliers suggest that there is some shift from long-term to short-term assets as a result of higher velocity. That may make sense, but only within a theoretical framework that explains what velocity and credit rationing mean. Otherwise, one has to grope for explanations. That's what Branson seems to be doing when he puts the foreigner at the back of the credit line. Some foreign bankers report that when there is tight money and credit rationing in the United States, large American firms get to the front of their line. As one banker put it, when DuPont knocks on your door, you don't turn him away. That may be equally true on the American side. If British Petroleum knocks on the U.S. banker's door, I don't think it is turned away either.

I am troubled by the specification for equation (5)-for short-term claims. There is a special dummy variable dealing with the voluntary foreign credit restraint program. I submit that no one who had not looked at the data would have specified the equation in this particular way. The program placed a ceiling on how much banks could lend abroad and that ceiling permitted some increase, but, in fact, banks stayed well below the 
ceiling. That is not explainable in terms of profit maximization. Branson's explanation is that banks wanted to operate without worrying about the ceiling. But they are used to working subject to reserve requirements, and there is a secondary market for reserves. The explanation really isn't very adequate.

The absence of the U.S. bond rate in the equation for long-term portfolio claims is also disturbing. The theory insists that the bond rate belongs there to represent the alternative U.S. asset. I know it is omitted because it does not work empirically. Maybe some other variables that appear are picking up the influence of the U.S. bond rate. This may be particularly true of the Eurodollar rate. That rate is supposed to reflect the demand for, and the supply of, dollars in Europe. When there is a gap between Regulation Q ceilings and money market rates in the United States, the Eurodollar rate also reflects U.S. excess demand for dollars coming from Europe, and thus U.S. rather than European monetary conditions. So it may at times be a proxy for the U.S. bond rate.

Another troublesome element in the long-term portfolio equation is the dummy for the interest equalization tax. When properly scaled, the tax should be usable as an explanatory variable in some continuous form-not merely as a dummy. In addition, since the Canadians are exempted, it would theoretically be preferable to have data separate for those countries subject to the tax and those exempted.

Long-term banking claims provide the classic example of the major special factors on the international side. Before 1963 it was the most predictable item in the balance of payments because it was a specialized business. Term loans by banks to foreigners were a very complicated, unrewarding kind of business so they were not used much. Before 1963, to forecast it, all one had to know was the delivery of ships to Norwegian shipowners because that was all that term loans financed. Then the interest equalization tax placed a 15 percent tax on long-term capital flows of securities but no tax on bank loans. It suddenly became very profitable to expand term loans. The whole concept changed. It was no longer in the same ball park. Quarterly flows went from $\$ 50$ million to $\$ 500$ million. That may still seem a small number to GNP experts but it is big in the balance of payments.

For all my criticism, I think the illustrative examples do teach Branson's lesson-to stay calm about capital flows when monetary policy shifts. Time must be allowed for the capital account to settle down. Some lessons 
may even be offered here for domestic monetary managers. If a certain amount of liquidity is injected into the domestic economy, some of that is going to leak abroad in the early quarters. Hence, the domestic impact will be held down initially. More mileage may be gotten out of the same injection of fuel subsequently, because there will be less leakage abroad.

John Kareken: Branson finds both comforting and discomforting implications of the new view. I basically agree with his verdict, but I'd like to elaborate and amend it on both sides. First, he finds it discomforting because monetary policy no longer offers a handle on international adjustments. That loss of an instrument applies for long-term, steady-state policy solutions. But the new view does not foreclose the use of monetary policy to finance temporarily some disturbance by raising or lowering interest rates successively over a few years. Monetary policy remains a way of dealing with temporary international adjustment problems.

On the other hand, Branson finds it comforting that monetary policy is more or less freed from the balance-of-payments constraint and can be determined largely by domestic considerations. That may or may not be right depending on the initial stock of reserves and the nation's consequent ability to accept a sizable one-shot loss. It is easy to imagine a country that goes bankrupt by easing monetary policy. I could even forgive someone who felt a bit nervous about a 10 percent loss of U.S. reserves. Even when the change in policy is a rather modest one, something may have to be added for loss due to speculation, particularly in the case of the United States if the distribution of demand between gold and dollars is at all affected. I can conceive of people understanding fully the stock-adjustment view of the world but estimating the probability of a parity change on the basis of the stock of reserves. That could cause some trouble in the short run.

Branson's simulations focus on an easing of monetary policy that represents a shift in the fiscal-monetary mix with no net impact on aggregate demand. Of course, monetary policy may also be used as a net stimulus to raise GNP. In that event it is clear that the capital outflow is going to be less than in the case of the same monetary easing to shift the mix. But then effects on the current account may become significant with the change in GNP.

The empirical work proceeds as though interest rates in the rest of the world are independent of United States demands for claims on foreigners. 
This does not seem to square with complaints we heard from Europeans when the Regulation $\mathrm{Q}$ ceiling was operative.

Other findings also raise suspicions that the equations may not have captured the real world. For example, the credit rationing variable appears significant only in the long-term portfolio equation and that is the one equation that does not directly reflect decisions by banks. I am not surprised that it is significant in that equation. If the nonbanking sector is rationed in its demand for bank loans, it can help finance itself in effect by buying fewer claims from foreigners. But I cannot explain why the variable is not significant in the other two equations. Also, a bewildering array of interest rates shows up in the equations. Perhaps it would have been more straightforward to take a weighted average of foreign interest rates and do or die with that variable.

I would be happier if I understood the role velocity is intended to play in the analysis. If it is meant to serve as a proxy for credit rationing, then I doubt that foreign velocity belongs in the specification. Since the data reject the inclusion of foreign velocity, this should be a welcome view. It probably ought not to be specified. When Europeans are being rationed out of their banks, the supply of claims offered to lenders will be affected, but the U.S. demand for claims will not be altered. If these are demand equations, the velocities can be interpreted as proxies for interest rates. Since there is an abundance of interest rate series, I do not know why a proxy should be needed.

Walter Salant: Branson makes the point that the stock-adjustment view of capital flows weakens one important objection to the "crawling peg" system of exchange rates. I think that a proponent of fixed rates could find reasons why this new view also makes flexibility of exchange rates less necessary. One reason it is thought necessary is that the fixed-rate system inhibits the freedom to use monetary policy. If capital flows reflect stock adjustments, central bankers ought to feel they have more freedom than they previously thought they had. If, for example, they want to tighten money to restrict domestic demand, they need not be so inhibited by the danger of attracting foreign funds, because they will recognize that the inflow of those funds will be temporary.

One might argue, in response, that a temporary inflow is sufficient to offset a restrictive policy, since monetary policy affects demand by operating on the stock of money or liquid assets. This response raises another 
question: whether domestic demand is affected by the proportion of a given money stock (or given stock of liquid assets) that is owned by foreigners. Suppose the effects on total demand depend not on the total supply of domestic money but only, or mainly, on the domestically owned portion of it. Then the effect of an increase in interest rates would not be fully, and maybe only slightly, offset by an equal increase in foreign-owned money. The question of whether domestic demand is affected by who owns the money supply, and of how that ownership is affected by changes in interest rates, may seem unimportant because foreign ownership of the U.S. money supply is so small. But that isn't the case for other countries.

William Branson: On the interpretation of velocity-it may be supplementing interest rates in measuring the opportunity cost of lending abroad. If domestic money markets tighten, velocity goes up; the opportunity cost of lending to foreigners also goes up. Presumably the velocity increase is picking up some kind of extra return on lending at home that may not be caught in any of the interest rate series, since credit markets are not perfect.

The best way to handle the interest equalization tax would be to adjust foreign interest rates for its effect. The tax was meant to create a wedge between gross and net foreign interest rates as they appear to U.S. potential lenders. I am planning to make that adjustment if I can find the appropriate interest rates to adjust. In their absence, something else had to be done in this paper.

I agree with John Kareken that under the new view, monetary policy can still be used to finance temporary, reversible perturbations in the United States balance of payments. If something temporarily happened to the current account, then it might be useful to raise interest rates for a while. But I am concerned lest U.S. interest rates might be pushed not just temporarily higher but, rather, permanently higher, because of anxiety about the balance of payments.

\section{General Discussion}

While most of the participants in the discussion expressed their support for the stock-adjustment approach, important reservations were noted by James Duesenberry, William Poole, and William Brainard. Duesenberry 
accepted the basic logic of this kind of stock approach to portfolios, but stressed that the speed of that stock adjustment and the factors influencing that speed are of great importance. The rapidity of the stock adjustment implied by Branson's results seemed too good to be completely credible. Duesenberry cited findings on domestic portfolio adjustments that indicated they may be spread over a period of several years. Especially for assets with long maturities, a large proportion is effectively locked in by the heavy transaction costs involved in portfolio shifting. The old stock is only gradually adjusted to its new equilibrium proportions. On the other hand, increases in assets can be handled much more flexibly.

Duesenberry argued that such a slow process would look, in practice, very much like a flow adjustment to anybody who is worrying about the balance of payments. The basic logic would be a portfolio stock adjustment, but the current flow variables would be governing the speed of adjustment. Duesenberry also suggested that the advent of convertibility in 1958 presented one case of a very large change in international returns and risks. If people had reacted to that change with the speed estimated in the Branson paper, there would have been an enormous outflow in a very short period of time.

William Poole reported on his own experience analyzing Canadian capital flows. He had found the empirical results distressingly sensitive to the sample period chosen. Although he preferred the stock-adjustment formulation on theoretical grounds, the flow formulation had yielded somewhat superior empirical results.

Poole stated his judgment that errors in the measurement of capital flows tend to bias the coefficients for speed of adjustment in the direction of indicating a faster shift than really occurs. Similarly, he felt that the difficulty of measuring the appropriate interest rate biases downward estimates of the interest elasticity. Both of these biases make the estimated effects of changes in interest rates inappropriately small.

William Brainard commented that the stock-adjustment view of the world was not reassuring if the desired proportions of portfolios change very substantially in response to small changes in yields. What makes Branson's results reassuring is their implication that long-run changes in proportions are quite small - that international assets are not very interest sensitive. But these results might signify merely that Branson's rather special specification is not adequate for capturing the lagged adjustments that continue after the initial few quarters. 
Branson replied by noting that long lags of adjustment following interest rate changes are implied by the opposing view and they just do not show up in the data. He also suggested that, because there may have been a long reaction to the change to convertibility in 1958 , one should not infer that people have long reaction times to changes in interest rates. The advent of convertibility was a major structural change; it is not a happy analogy to interest rate changes. People in these markets are continually watching interest rates, and they have every incentive to translate yield differentials into prompt portfolio action. 